DOI https://doi.org/10.32841/2409-1154.2021.49-1.27

\author{
Лелешко О. О., \\ аспірант кафеери германських мов і перекладознавства \\ Дрогобицького державного педагогічного університету імені Івана Франка
}

\section{ЧАСТИНОМОВНІ МОДЕЛІ} \\ АНГЛОМОВНИХ ВІЙСЬКОВИХ ТЕРМІНІВ
}

Сліпецька В. Д., кандидат фбілологічних наук, доцент каббедри германських мов і перекладознавства Дрогобицького державного педагогічного університету імені Івана Франка

\begin{abstract}
Анотація. У статті проведено визначення та дослідження найтиповіших частиномовних моделей англомовних військових термінів. Актуальність цього дослідження полягає у тому, що саме аспект частиномовних моделей англомовних військових термінів до цього не розглядався в українському науковому дискурсі. Усі підрахунки у цій науковій розвідці були здійснені на основі термінологічної вибірки, котра була заздалегідь підготована для цього дослідження. У процесі аналізу англомовних військових термінів всі термінологічні одиниці були розділені на такі дві категорії, як однокомпонентні та багатокомпонентні. Далі всі терміни з категорії багатокомпонентних були розділені на окремі підгрупи відповідно до кількості компонентів. Після поділу за кількістю компонентів проведено маркування за частиномовними моделями. Статистичні розрахунки, категоризація та маркування за частиномовними моделями проводились у середовищі Microsoft Excel.

За результатом статистичних підрахунків підтверджені попередні позиції дослідників компонентного складу термінів про те, що багатокомпонентні терміни становлять більшість у всіх терміносистемах. Це пояснюється тим, що багатокомпонентні терміни виявляють більшу здатність до конкретизації значень. Також було підтверджено, що найбільш розповсюдженою категорією серед багатокомпонентних термінів $є$ саме двокомпонентні. Проте дослідження також указало на таке: незважаючи на свою розповсюдженість, ця категорія не може вважатися найбільш продуктивною. У процесі дослідження також проаналізовано найбільш продуктивні та середньопродуктивні частиномовні моделі англомовних військових термінів. Окрім цього, була помічена тенденція до зростання різноманітності частиномовних моделей відповідно до кількості компонентів у термінах, а збільшення різноманітності частиномовних моделей зростає у всіх категоріях. Аналіз частиномовних моделей, що був здійснений у цьому дослідженні, підтвердив твердження, що висувалось іншими дослідниками зі сфери термінології, яке полягало в тому, що іменник $\epsilon$ однією 3 найпоширеніших частин мови в будь-якій професійній термінології.

Ключові слова: англомовні військові терміни, терміносистема, частиномовна модель, багатокомпонентний термін.
\end{abstract}

Постановка проблеми. Об'єктом дослідження є частиномовні моделі англомовні військові терміни, що використовуються в збройних силах Сполучених Штатів Америки, Великої Британії та Канади. Загальна кількість військових термінів, які були використані у цьому дослідженні, становить 5000 одиниць. Ці терміни були відібрані шляхом методом суцільної вибірки з лексикографічних джерел, як-от DOD Dictionary Of Military And Associated Terms, NATO Glossary Of Terms And Definitions (English And French), The Official NATO Terminology Database, Військовий Стандарт 01.030.001-2020 (Видання 1), Manual Of Abbreviations Department Of National Defence And The Canadian Armed Forces, MOD Acronyms And Abbreviations.

Предметом дослідження є найбільш продуктивні частиномовні моделі англомовних військових термінів та їх характеристики.

Метою статті $є$ виявлення найпродуктивніших та середньопродуктивних частиномовних моделей термінотворення в сучасних військових терміносистемах Сполучених Штатів Америки, Великої Британії та Канади та взаємозв'язок з їх структурними характеристиками. У процесі роботи використані такі методи дослідження, як лінгвістичний опис, компонентний аналіз та статистичний.

Виклад основного матеріалу. Основним джерелом інформації для цього дослідження $є$ вибірка військових термінів, які були відібрані шляхом суцільної вибірки з лексикографічних джерел військового спрямування. Загальна кількість відібраних термінів становить 5000 одиниць. За своїм складом проаналізовані терміни та їх частиномовні моделі представлені майже всіма самостійними частинами мови та деякими службовими. У статті, присвяченій аналітичні номінації термінів, Н.В. Разбєгіна зазначає: «Навіть попри актуальність та активні дослідження неоднослівних термінів, у науковому дискурсі відсутня узгоджена дефініція для них. Мовознавці використовують такі назви: «багатокомпонентний термін», «полікомпонентний термін», «складений термін», «складний термін», «складена назва», «складене найменування», «термінологічне сполучення», «термінологічне словосполучення»», «термін-словосполучення», «терміносполучення», «словосполучення термінологічного типу», «словосполучення термінологічного характеру» $[1$, с. 346]. Із метою уникнення неточностей для зручності у цьому дослідженні замість поняття «неоднослівний термін» буде використано «багатокомпонентний термін».

Аналізуючи терміни, які було внесено до вибірки, виявлено 797 однокомпонентних термінів та 4203 багатокомпонентних термінів, що у відсотковому співвідношенні становить 15,94\% та 84,06\% відповідно. Також був проведений підрахунок термінів за кількістю компонентів у їх структурі та були отримані 
такі результати: 1) двокомпонентні - 2277 (45,54\%); 2) трикомпонентні- $1335(26,70 \%)$; 3 ) чотирикомпонентні-407 (8,14\%); 4) п’ятикомпонентні - 132 (2,64\%); шестикомпонентні - 38 $(0,76 \%)$; семикомпонентні - $11(0,22 \%)$; восьмикомпонентні 3 (0,06\%). У працях, присвячених структурі термінів, науковці пояснюють домінацію багатокомпонентних термінів таким аргументом: «Перевага надається термінам-словосполученням, оскільки вони здатні найбільш повно відобразити необхідні специфічні риси поняття, яке називається аналітичними термінами» [2, с. 104]. Також вищевказані показники підтверджують твердження вченого С. Гриньова який зазначає, що 60-95\% термінів у сучасних європейських мовах - це багатокомпонентні одиниці [3, с. 137].

Після розподілу та аналізу термінів за кількістю компонентів на основі підготовленої для цього дослідження вибірки англомовних військових термінів здійснено аналіз та визначено найпродуктивніші частиномовні моделі у термінах із різною кількістю компонентів. У дослідженні були використані такі умовні позначення для частин мови: $\mathrm{N}$ - noun; $\mathrm{A}$ - adjective; $\mathrm{V}$ verb; $\mathrm{P}$ - pronoun; Adv - adverb; $\mathrm{C}$ - conjunction; D - determiner; Prep - preposition. Окремо у цьому дослідженні також були проаналізовані однокомпонентні терміни на предмет того, якими частинами мови вони позначаються. Відповідно до підрахунків однокомпонентних термінів визначено, що більшість термінів є саме іменниками (91,5\%), тоді як прикметники, прислівники та дієслова становлять лише $8,5 \%$ від загальної суми однокомпонентних термінів (прикметники - 3,5\%; прислівники - 0,5\%; дієслова - 4,5\%). У співвідношенні до інших багатокомпонентних термінів у вибірці загальна кількість однокомпонентних термінів у вибірці становить лише 15,94\%.

Наступною та найбільшою категорією термінів є двокомпонентні, кількість яких становить 45,54\% від загальної кількості всіх термінів у цьому дослідженні. У цій категорії найбільш розповсюдженими частиномовними моделями $€$ іменник + іменник $(\mathrm{N}+\mathrm{N}-51,56 \%)$ та прикметник + іменник $(\mathrm{A}+\mathrm{N}-$ 42,60\%). Решта моделей становлять доволі низький відсоток: дісслово + іменник $(\mathrm{V}+\mathrm{N}-2,81 \%)$, іменник + дісслово (N+V $0,66 \%)$ та прийменник + іменник $(\mathrm{Adv}+\mathrm{N}-0,66 \%)$. У цій категорії простежується тенденція до того, що звичним формувальним елементом у кожній із наведених частиномовних моделей $€$ іменник. Отримані результати збігаються 3 твердженням С. Гриньова, що «найбільш простим та найбільш розповсюдженим видом термінів в англійській мові є двокомпонентні атрибутивні словосполучення, які складаються 3 основного елемента, що виражений іменником, та атрибутивного елемента» [3, с. 137]. В.Д. Сліпецька у своїй праці «Англомовна Термінологія Штучного Інтелекту В Контексті Інших Терміносистем (Досвід Лінгвостатистичного Аналізу)» зазначає, що «домінування утворень типу $N \boldsymbol{N}$ серед інтрагалузевих термінів пояснюється тенденцією до лаконічності та спрощення мовних форм і широким діапазоном семантичних відношень, які здатна передавати ця конструкція. Використання моделі $N N$, безумовно, відповідає потребам мовця, тут - автора наукового твору» [4, с. 11]. Варто зазначити, що в цьому дослідженні не враховано належність термінів до однієї з груп, що були наведені в цитаті вище (інтрагалузеві, екстрагалузеві, загальнонаукові). У схожих за темою дослідженнях висувають подібні припущення щодо розповсюдженості вищезазначених частиномовних моделей $[5$, с. 44]. С. Гриньов також зазначає, що найбільш розповсюдженими частиномовними моделями між двокомпонентних термінів є моделі $\mathrm{N}+\mathrm{N}, \mathrm{A}+\mathrm{N}, \mathrm{V}+\mathrm{N}$. Він також пояснює, що популярність цих частиномовних моделей пов'язана 3 тим, що вони утворені шляхом синтаксичного термінотворення, який $є$ найбільш популярним засобом поповнення термінологій. Цей спосіб полягає у перетворенні звичайних вільних словосполучень у складні «еквіваленти слів». Завдяки цьому способу утворюються 60-95\% складу різноманітних термінологій європейських мов. Дослідник також зазначає, що «серед основних властивостей термінів словосполучень разом зі стійкістю (цільністю номінації), що зумовлена функцією найменування одного поняття, вказується на їх номінативний характер і атрибутивний (визначальний) вид зв'язку елементів, iз яких вони складаються. Це означає, що є об'єктивні передумови виокремлення і фіксації термінів словосполучень із тексту і визначення їх основних моделей, що може бути використано для створення алгоритму автоматичного розпізнавання складених термінів у тексті» [3, с. 137].

Другою за кількістю групою термінів у дослідженні є трикомпонентні, які становлять $26,70 \%$ від загальної кількості всіх термінів, використаних у дослідженні. За підрахунками визначено, що двома домінувальними частиномовними моделями в трикомпонентних термінах є іменник + іменник + іменник $(\mathrm{N}+\mathrm{N}+\mathrm{N}-35,81 \%)$ та прикметник + іменник + іменник $(\mathrm{A}+\mathrm{N}+\mathrm{N} 31,01 \%)$. Наступними за кількістю моделі прикметник + прикметник + іменник $(\mathrm{A}+\mathrm{A}+\mathrm{N}-9,51 \%)$, іменник + прийменник + іменник $(\mathrm{N}+\mathrm{Prep}+\mathrm{N}-8,99 \%)$ та іменник + прикметник + іменник $(N+A+N-4,42 \%)$. Аналізуючи вищевказані статистичні дані, можна зробити висновок, що для трикомпонентних термінів типовими елементами частиномовних моделей $є$ іменник та прикметник, оскільки вони трапляються у п'яти найбільш розповсюджених частиномовних моделях цієї групи термінів. Надаючи характеристику трикомпонентним термінам, С. Гриньов говорить, що, «як правило, трикомпонентні термінологічні словосполучення утворюються на базі двокомпонентних словосполучень, що характеризуються більш тісними структурно-семантичними співвідношеннями», та називає їх похідними словосполученнями. Він також зазначає, що саме різноманітність типів похідних структур зумовлює різноманітність формально-семантичних структур трикомпонентних словосполучень [3, с. 142]. Варто також зазначити, що найбільш продуктивні частиномовні моделі в категорії трикомпонентних термінів за своєю структурою мають схожі елементи з двокомпонентними термінами. Це спричинено тим, що терміноодиниці, котрі мають модель $\mathrm{N}+\mathrm{N}$ та A + N, розширюються шляхом додавання до них іменника або прикметника. Типовим є додавання прикметника саме 3 метою конкретизації того поняття, яке окреслює термін.

Наступною категорією, котра має найбільшу варіативність частиномовних моделей, є чотирикомпонентні терміни. Ця категорія продовжує демонструвати схожу тенденцію за складом частиномовних моделей. Із 52 варіантів частиномовних моделей найбільш розповсюдженими серед чотирикомпонентних військових термінів $€$ такі: іменник + іменник + іменник + іменник (NNNN - 26,04\%, наприклад: rescue combat air patrol); прикметник + іменник + іменник + іменник (ANNN 27,87\%, наприклад: regional response coordination center). Дві вищевказані моделі є схожими за своїми властивостями на трикомпонентні та двокомпонентні терміни, оскільки вони пере- 
важають за кількісним показником у своїй категорії та схожі за своїм складом та структурою. Під час розгляду п'ятикомпонентних термінів визначено такі найбілыш типові частиномовні моделі: прикметник + іменник + іменник + іменник + іменник (ANNNN - 11,36\%), прикметник + прикметник + іменник + іменник + іменник (AANNN - 9,09\%), іменник + іменник + іменник + іменник + іменник $(\mathrm{NNNNN}-8,33 \%)$, прикметник + іменник + сполучник + іменник + іменник (ANCNN - 8,33\%). Дещо відмінні результати були отримані після підрахунку типових частиномовних моделей у шестикомпонентних термінах. Три найбільш розповсюджені моделі виглядають так: прикметник + прикметник + прикметник + сполучник + прикметник + іменник (AAACAN $-13 \%)$, прикметник + іменник + іменник + сполучник + іменник + іменник $(\mathrm{ANNCNN}-8 \%)$, іменник + сполучник + іменник + іменник + іменник + іменник $(\mathrm{NCNNNN}-8 \%)$. Як ми можемо помітити, принциповою відмінністю у цій категорії багатокомпонентних термінів $є$ присутність сполучника у складі частиномовної моделі. Можемо зробити припущення, що це спричинено нагромадженістю конструкції шестикомпонентних термінів, що потребує сполучного елементу, щоб передати логічне значення.

Окремо також важливо відзначити й середньопродуктивні моделі для термінів із різною кількістю компонентів. Серед двокомпонентних термінів до цієї категорії можна зарахувати поєднання дієслова та іменника $(\mathrm{V}+\mathrm{N}-2,81 \%)$. Поміж трикомпонентних термінів до середньопродуктивних моделей можна зарахувати такі: прикметник + прикметник + іменник $(\mathrm{A}+\mathrm{A}+\mathrm{N}-$ $9,21 \%)$, іменник + прийменник + іменник $(\mathrm{N}+\mathrm{Prep}+\mathrm{N}-8,99 \%)$, іменник + прикметник + іменник $(\mathrm{N}+\mathrm{A}+\mathrm{N}-4,42 \%)$. Порівняно 3 найбільш продуктивними частиномовними моделями середньопродуктивні значно поступаються за кількістю, оскільки разом вони становлять лише $6 \%$ від загальної кількості термінів. За результатами підрахунку середньопродуктивні моделі чотирикомпонентних термінів представлені такими моделями: прикметник + прикметник + іменник + іменник (AANN - 5,90\%), прикметник + іменник + прийменник + іменник (ANPrepN 4,67\%), іменник + прикметник + іменник + іменник (NANN 3,93\%). П' ятикомпонентні терміни відрізняються такими двома частиномовними моделями: іменник + сполучник + іменник + іменник + іменник $(\mathrm{NCNNN}-6,68 \%)$, іменник + іменник + сполучник + іменник + іменник (NNCNN - 6,06\%). Під час аналізу цих частиномовних моделей можна помітити схожість зі структурою найбільш продуктивних шестикомпонентних моделей, які у своєму складі також містять сполучник. У цьому разі також можемо зробити припущення, що така модель спричинена компонентною нагромадженістю терміна. Також використання саме такої конструкції може бути зумовлене потребою в логічному та зв'язному переданні значення певного терміна. Серед шести-, семи- та восьмикомпонентних термінів важко виокремити саме середньопродуктивні моделі, оскільки вони представлені одиничними випадками. Решта частиномовних моделей представлені в одиничному екземплярі.

Типовою тенденцією, котра простежується у цьому дослідженні, є домінація частиномовних моделей, до складу яких входять такі частини мови, як іменник та прикметник. Також ми можемо спостерігати, що більшість термінів (35\% від загальної кількості термінів) була утворена саме поєднанням двох, трьох або чотирьох іменникових основ. Другою значу- щою групою є терміни, що були утворені шляхом додавання до іменникових основ прикметника, котрий перебуває на першому місці в конструкції частиномовної моделі. Загальна кількість термінів цієї моделі становить 30\% від загальної кількості термінологічних одиниць у дослідженні. Цей тип частиномовних моделей можна визначити як найбільш продуктивний саме серед англомовних військових термінів. Так, наприклад, серед частиномовних моделей двокомпонентних термінів 56\% у своєму складі містить іменник та 35\% - прикметник. Якщо проводити аналогічний аналіз серед трикомпонентних термінів, то помічаємо, що 91\% частиномовних моделей мають у складі іменники. На підставі вищенаведених статистичних даних можемо стверджувати, що ці частиномовні моделі $€$ характерними під час творення військових англомовних термінів. У процесі дослідження помічена така закономірність: разом зі збільшенням компонентів у складі терміна також збільшується варіативність та кількість частиномовних моделей. Пікові показники цієї тенденції прослідковуються саме в чотирикомпонентних термінів, які налічують 52 унікальні частиномовні моделі. Проте надалі цей показник іде на спад, оскільки прослідковуються такі показники: 47 частиномовних моделей у категорії п'ятикомпонентних термінів, 24 частиномовні моделі в шестикомпонентних термінах, 10 та 2 частиномовних моделей у категоріях семи- та восьмикомпонентних термінів відповідно. Дво- та трикомпонентні терміни становлять більшість термінів у вибірці (72\%), мають меншу різноманітність частиномовних моделей. За підрахунками двокомпонентні терміни мають 17 унікальних моделей, а трикомпонентні - 35 . В.Д. Сліпецька зазначає: «До найважливіших характеристик багатокомпонентних термінів належать частиномовна модель та термінотвірний тип терміна» $[4$, с. 10]. Цю думку також підтримують Л.Й Цьох та Т.В Коваль та дають такі коментарі: «Однією з важливих характеристик багатокомпонентних термінів є їх частиномовна модель, котра визначає структуру мовної одиниці. Є залежність між частиномовною моделлю та категоріальним видом терміна» [5, с. 44].

Одним із найважчих завдань у таких дослідженнях є саме підрахунок та отримання кількісної інформації про типи частиномовних моделей, оскільки цей процес потребує кропіткої роботи з їх відбору та обчислення. У цьому дослідженні для статистичного підрахунку даних були створені окремі таблиці, в яких були зазначені частиномовні моделі та кількість термінів, яким притаманне їх використання. Таблиці такого плану були створені для кожної категорії термінів залежно від кількості їх компонентів. Усі статистичні розрахунки, категоризація та маркування за частиномовними моделями проводились у середовищі Microsoft Excel.

Висновки. За результатом статистичних підрахунків багатокомпонентні терміни становлять більшість. Л. Гаращенко дає досить розлоге пояснення цьому результату: «Терміни - словосполучення, що виявляють більшу здатність до конкретизації значень завдяки можливості надавати уточнювальні галузеві характеристики загальновживаним словам. Результати цього дослідження також збігаються 3 результатами термінознавчих розвідок [6, с. 224]. Серед багатокомпонентних термінів визначено найбільшу категорію термінів, якою є двокомпонентні. Незважаючи на домінацію за цим критерієм, цю категорію не можна назвати найпродуктивнішою з точки зору різноманітності частиномовних моделей. 
Проаналізовано найбільш продуктивні та середньопродуктивні частиномовні моделі. Найбільш продуктивною категорією багатокомпонентних термінів за кількістю частиномовних моделей виявились чотирикомпонентні. У дослідженні виявлено 52 відмінні частиномовні моделі.

Окремо також зазначено, що різноманітність частиномовних моделей зростає відповідно до кількості компонентів у терміні. Тенденція полягає в тому, що збільшення різноманітності частиномовних моделей зростає у всіх категоріях.

Результати цього дослідження перегукуються з дослідженнями інших науковців та підтверджують попередні наукові розвідки. Наукова новизна цієї публікації полягає саме в аналізі частиномовних моделей у співвідношенні з їх структурними характеристиками, оскільки в більшості інших аналізів із цієі теми порівняння проводиться на основі інших критеріїв. Також необхідно зазначити, що актуальність цього дослідження спричинена відсутністю розвідок саме в аспекті військових терміносистем.

Аналіз частиномовних моделей також підтвердив твердження, яке фігурувало у попередніх дослідженнях, яке полягало в тому, що іменник $є$ однією $з$ найпоширеніших частин мови в будь-якій професійній термінології. Результати цієі публікації надалі можуть використовуватись для більш детального аналізу частиномовних компонентів англомовних військових термінів та їх відношення з іншими критеріями термінів, як-от їх належність до певних груп термінів (інтрагалузевих, екстрагалузевих та загальнонаукових).

\section{תimepamypa:}

1. Разбєгіна Н.В. Аналітичні номінації термінів міжнародного права. Наукові записки Національного університету «Острозька академія». Серія «Філологічна». 2015. Вип. 58. С. 346-349.

2. Даниленко В.П. О терминологическом словообразовании. Вопросы языкознания. 1973. № 4. С. 76-85.

3. Гринев С.В. Введение в терминоведение. Москва, 1993. 310 с.

4. Сліпецька В.Д. Англомовна термінологія штучного інтелекту в контексті інших терміносистем (досвід лінгвостатистичного аналізу): дис. ... канд. філол. Наук : 10.02.04. Київ, 2008. 347 с.

5. Цьох Л.Й, Коваль Т.В Структурна класифікація термінів українських наукових текстів в галузі комп'ютерної лінгвістики: якісні та кількісні характеристики. Розвиток філології та лінгвістики на сучасному історичному етапі (Одеса, 11-12 грудня 2020 р.) Одеса, 2020. С. 43-47.
6. Гаращенко Л.Б. Аналітизм як тип термінологічної номінації. Лінгвістичні дослідження: Збірник наукових праць Харківського національного педагогічного університету імені Г.С. Сковороди. Харків, 2012. Вип. 34. С. 223-228.

Lemeshko O., Slipetska V. Part-of-speech models of anglophone military terms

Summary. The given article contains research results that concern the most common part-of-speech models of anglophone military terms. The topicality of this study is based on the fact that the very aspect of part-of-speech models of Anglophone military terms had not been researched in Ukrainian scientific discourse. All calculations in this research paper were conducted based on a selection of military terms that was compiled specifically for this article. During the analysis of anglophone military terms, all items were subdivided into two categories one-component terms and multi-component terms. Further, all terminological units from the multi-component category were split into subgroups according to the number of components. After the split, all the components were tagged with their partof-speech model. Statistical calculations, categorization, and part-of-speech tagging were performed with help of Microsoft Excel software.

The statistical calculations which were gathered in this research prove previous studies from the field of component composition of terms that the multi-component terms make up the vast majority in all terminological systems. It is explained by the fact that multi-component terms pose a greater ability to specify meaning. It was also confirmed that the most common category among multi-component terms is two-component terms. However, the study also indicated that, despite its prevalence, this category cannot be considered to be the most productive one. The study also analyzed the most productive partof-language models of Anglophone military terms. In addition, a trend has been noticed that the diversity of part-of-speech models tends to increase alongside the number of components of the term. It was also noticed that the increase of part-ofspeech models diversity is a specific feature for all terminological categories. The analysis of part-of-speech models that was carried out in the given article confirmed the statement made by other researchers in terminology, namely that the noun is one of the most common parts of language in any professional terminology.

Key words: Anglophone military terms, term system, partof-speech model, multi-component term. 